\title{
OBJECTIVES OF ISLAMIC BANKS IN THE MANAGEMENT OF ASSET AND LIABILITY: A DECISION PROCESS OF DERIVING PRIORITY.
}

\author{
Karmila Hanim Kamil* \\ Faculty of Science \& Technology \\ Universiti Sains Islam Malaysia (USIM) \\ Bandar Baru Nilai, Negeri Sembilan \\ E-mail: karmila@usim.edu.my \\ Abdul Ghafar Ismail \\ School of Economics \\ Faculty of Economics and Management \\ Universiti Kebangsaan Malaysia (UKM) \\ Bandar Baru Bangi, Selangor Darul Ehsan \\ E-mail: agibab@ukm.my \\ Shahida Shahimi \\ School of Economics \\ Faculty of Economics and Management \\ Universiti Kebangsaan Malaysia (UKM) \\ Bandar Baru Bangi, Selangor Darul Ehsan \\ E-mail: shahida@ukm.my
}

\begin{abstract}
The development of Islamic banking systems has gained great momentum as an essential addition to the global financial market including Malaysia. Nevertheless, clients who supported the system had formed some expectations other than the mechanics of its operations. Above all, they expect that other features like contribution of Islamic banking towards a more equitable distribution of income and wealth, promoting social justice and increased equity participation in the economy are equally essential to become the goals of the Islamic banking operations. Thus, the existence of Islamic banking can be seen as not merely an effort to comply with the shariah, but also to realize the maqasid al-shariah. Hence, the ultimate measure of the worth of a business activity, including Islamic banking, is the value it creates that may contributes to the effectiveness of wealth circulation and resources allocation for the benefits of everyone in the society. This study proposes the usage of AHP methodology in deriving the priority choice in the allocation of financial resources towards the multi-objectives model of Islamic banking, which take into consideration both economic and social objectives. By trying to derive the appropriate weights for each of the objective involved, the results of the study have shown interesting variations from two different groups of judgments and opinions regarding this matter. These have proved that further consideration is needed by the decision makers in IBIs in an effort to reduce the gap between economic and social objectives in the Islamic banking operations as a whole.
\end{abstract}

Keywords: Objectives of Islamic Bank, Asset and Liability Management, Analytical Hierarchy Process (AHP).

\footnotetext{
${ }^{*}$ Corresponding author
} 


\section{Introduction}

The growth of Islamic banking systems has spread outside its traditional borders of Muslim economies, which includes other western countries. Currently, the total number of Islamic financial institutions has increased throughout the world with more than 300 institutions in operation, spanning over 75 countries in East and West. This trend demonstrates the significant rise on the demand and interest of financial institutions towards Islamic banking system. Among the main drivers that have contributed to the strong growth of Islamic banking system includes the high demand from Islamic societies for Shariah-compliant financial products; deficiencies in the conventional system which make people search for alternatives; encouraging interest and awareness among conventional investors seeking ethical principles investments; continuous enhancement towards Islamic banking legal and regulatory framework; the capacity of the institutions to develop financial instruments that could tailor to the needs of corporate as well as individual investors; and the strong moral orientation of Islamic finance itself (Hasan and Dridi, 2010, Siddiqi, 2002).

Despite competitive market environment as a result of globalization and financial liberalization, Islamic banking persists to make significant achievement year to year as awareness of its advantages continue to spread. By parting itself from riba, maysir and gharar which becomes the crux of Islamic banking system distinction from conventional banking, Islamic banking had move forward with successfully offering an impressive range of financial products which are adhering to shariah principles to cater the increasing needs of Muslims customers. Apart from that, some non-Muslims customers are also interested to participate in Islamic banking because they consider it to be commercially sound.

Although the performance of the Islamic banking system has been encouraging, there is still room to improve on the lacking aspects perceived by the clients who supported the system. Clients had formed some expectations other than the mechanics of Islamic bank's operations which are normally expressed in the minutiae of transactions with regards to the products and services offered. Above all, they expect that there is more internalization of Islamic features and values to Islamic banking system than merely abolition of riba, maysir and gharar in the whole operations of the Islamic banks. Authors like Arif (1988), Chapra (1982) and Ismail (2010) strongly argued that other features like contribution of Islamic banking towards a more equitable distribution of income and wealth, promoting social justice and increased equity participation in the economy are equally essential to become the objectives of the Islamic banking operations. Thus, the existence of Islamic banking can be seen as not merely an effort to comply with the shariah, but also to realize the maqasid al-shariah (Ismail, 2011).

Referring to the general roles of Islamic Banking Institutions (IBIs) as financial intermediary, several resemblances do exist when compared to conventional banks. However, many prominent Islamic economic scholars such as Chapra (1985), Siddiqui (2000), and Naqvi (2003) strongly state that IBIs are distinctly different from conventional banks. The nature, outlook and its operations are centered towards the objectives of social welfare orientation whereby, eradicating all elements of inequity, injustice, exploitation and oppression in society is practiced. In line with the Islamic teachings, social interests therefore should become the focal direction for IBIs in any of their decisions process, besides targeting on making profit. Although economic objectives are desirable, it is not a goal in itself. What is more crucial is the motivation of IBIs to counterbalance a conception of society needs and social collaboration as to seek value maximization within the ethical parameters of Islam (Rafik and Jamal, 2005, Saeed, Ahmed, and Mukhtar, 2001). This reveals the heart of Islamic principles where the objectives of any business venture or activities must be guided by the purpose to further contribute to the welfare of the community. Hence, the ultimate measure of the worth of a business activity, including Islamic banking, is the value it creates that may contributes to the effectiveness of wealth circulation and resources allocation for the benefits of everyone in the society. 


\section{Literature review}

Business objective is a goal that an organization sets for itself. Common examples include profitability, sales growth, or return on investment. These goals act as the foundation upon which the strategic and operational policies adopted by the organization will be based on (Griffin, 2011). As a shariah-oriented business entity, it is therefore important for IBIs to assimilate the Islamic economic philosophy and principle in the formulation process of their business objectives. This is because the intermediation functions in a particular IBIs will reflect their business objectives as to whether they are truly upholding the Islamic principles (Haron, 1995).

Similar to any other commercial financial institution, an IBIs may be established along the principles of joint-stock corporations to render services for the purpose of achieving their business objectives (ISRA, 2011). However, its activities which includes acquire funds from the public, use the acquired funds in profitable activities and render chargeable services, should be operated within the realms of shariah teachings which suggest that not only self-interest but social interest is to be served as well (Chapra, 2000). Khan (2003) pointed out that if the only difference between IBIs and conventional banking practices is in terms of whether the business is interest-based or not, then the non-Islamic financial institutions probably can deliver Islamic services in a better way than IBIs. Thus, he asserts that a distinct aspect of an Islamic oriented business entity is the social dimension in its operations.

As to realign the needs of Islamic economic value system, Naqvi (2003) asserts that IBIs are required to focus more towards the enlargement on the concept of maqasid al-shariah in their business operations. Despite remaining responsive in fulfilling their economic-objectives, IBIs should have taken a measure for the reorientation of their business operations by expanding social-objective aspects, which ponder upon diverse society needs particularly on the matter of welfare and justice. Islamic economists are of opinion that although competitions in the market do exist, there should not be any conflict between these two objectives. They argue that both objectives could be arranged to work in co-operation where social priorities are served alongside economic oriented profit maximizing objectives (Chapra, 2000). Within the harmonized framework, IBIs could fulfill various shareholders as well as other society such as depositors, employees, customers and community claims at large to financial resources in an economically and socially efficient manner based on the teachings of Islam.

Against this backdrop, the intermediation function by IBIs has created a diversity of assets and liabilities, which reflect a variety of characteristics in terms of economics as well as social considerations that involved directly or indirectly with the bank's business operation. (Iqbal and Llewellyn, 2002). In highly competitive dual-banking systems like Malaysia, the good quality on the management of financial resource allocation of bank funds or commonly known as asset and liability management (ALM) is considered as one of the success factors for IBIs. As ALM is generally accepted as the primary operational function in banks, it is expected that the process on the mobilization and allocation of bank funds deals with the efficient management towards fulfilling multiple bank management objectives (Bidabad and Allahyarifard, 2008). For the ALM function in IBIs, conflicts might exist on the consideration between economic-objectives and social-objectives.

Therefore, the major purpose of present study is to investigate the priority choice or relative importance on the multi-objectives model of Islamic banks particularly in the management of sources and uses of bank funds or ALM, which take into consideration both economic and social objectives of IBIs. This study applies the analytic hierarchy process (AHP) in deriving priorities on the objectives of Islamic banks for the above matter. Ultimately, the findings of this study would provide some indications to the decision makers in Islamic banks to consider on how to efficiently manage the assets and liabilities within limited bank's resources based on the multi-objectives of Islamic bank. 


\section{Methodology}

\subsection{The Multi-Objectives Model of an IBI}

Based on the discussion above, IBIs should be viewed as a particular type of banks that operates to maximize an objective function which has a blend of economic-objectives and social-objectives. Accordingly, this study proposes three main economic-objectives that seem to be the most important in any commercial IBI mainly in ALM function and two main social-objectives as envisioned and deeply inscribed in the maqasid al-shariah. The economic-objectives are further divided into three subobjectives, while five other sub-objectives are for social-objectives. Taken together, there are eight specific objectives of IBI in the management of assets and liabilities that served for diverse interest including shareholders, depositors, employees, customers and communities, as shown in Table 1. The selection of the criteria for main and sub-objectives of Islamic bank are based from literature and experts' opinions (Asyraf Wajdi, 2008). This paper intended to introduce the use of AHP approach in determining the priority choice in the management of assets and liabilities towards the multi-objectives of Islamic banks by getting the appropriate weight for each of the objective involved.

Table 1. Multi-Objectives of Islamic banks in the asset and liability management

\begin{tabular}{|l|l|l|}
\hline Main objectives & Sub-objectives & Description \\
\hline Profit and growth & Maximizing profitability & Ratio of profitability \\
\hline \multirow{2}{*}{ Liquidity } & $\begin{array}{l}\text { Maintaining sufficient amount of cash } \\
\text { flows }\end{array}$ & Ratio of liquidity \\
\hline Solvency & Managing risks & Ratio of solvency \\
\hline \multirow{3}{*}{ Fair and justice } & Providing fair return to shareholders & Amount attributable to shareholders \\
\cline { 2 - 3 } & Providing fair return to depositors & Amount attributable to depositors \\
\cline { 2 - 3 } & Providing relevant benefits to employees & Ratio of employee benefits \\
\hline \multirow{2}{*}{ Social welfare } & Redistribution of income or wealth & Amount of zakat contribution \\
\cline { 2 - 3 } & Investment in public interest & Ratio of investment in real sectors \\
\hline
\end{tabular}

\subsection{The Analytic Hierarchy Process (AHP) approach}

AHP approach can be traced back to the early 1970s in response to the scarce resources allocation and planning needs for the military (Saaty, 1980). Over the years, it has received a wider attention in various fields as one of the decision-making techniques for researchers and decision makers due to its comprehensive framework. AHP considers both qualitative and quantitative aspects to research and combines them into a single empirical analysis. It uses qualitative way to decompose an unstructured problem into a systematic decision hierarchy based on the process of reviewing the related literature and interviewing experts. In the quantitative sense, it employs a pair-wise comparison to execute the consistency test to validate the consistency of responses towards the questionnaire.

The basic AHP process includes five stages, namely: (1) establish a hierarchy; (2) design the pairwise comparison questionnaire; (3) calculate the criteria weighting; (4) calculate eigenvector and (5) consistency test. In stage (3) and (4), AHP uses prioritization methods as the methods to derive priorities vector or weights from pairwise comparison matrices (Saaty, 1990). The most common and well-known prioritization method in AHP is Eigenvector method, which was proposed by Saaty (1977) and therefore utilized in this study. There are other methods as well such as Modified Eigenvectors, Additive Normalization, Direct Least Squares, Weighted Least Squares, Logarithmic Least Squares (Geometric Means), Logarithmic Goal Programming, and Fuzzy Preferences Programming. In stage (5), lies one of the significance in AHP method where consistency ratio (CR) is used to verify the credibility and 
reasonability of evaluation, and to check whether there is inconsistent causality or conflicts in subjective judgments. The CR is acceptable if it does not exceed 0.1 (Saaty, 1980). The definition of consistency index showed as follows:

$$
C I=\left(\lambda_{\max }-n\right) /(n-1), \text { and } C R=\left(C I / R I_{n}\right)
$$

The positive reciprocal matrix generated by valuation yields different consistency index (CI) values at each level. These CI values are called random indexes. The $\lambda_{\max }$ is the maximized eigenvector of a pairwise comparison matrix. The $n$ is an attribute of the matrix, and $R I_{n}$ is a random index as shown in Table 2 (Saaty, 1980).

Table 2. Random index

\begin{tabular}{|l|l|l|l|l|l|l|l|l|l|l|l|l|l|l|}
\hline $\mathrm{N}$ & 2 & 3 & 4 & 5 & 6 & 7 & 8 & 9 & 10 & 11 & 12 & 13 & 14 & 15 \\
\hline R.I. & 0 & 0.58 & 0.90 & 1.12 & 1.25 & 1.32 & 1.41 & 1.45 & 1.49 & 1.54 & 1.48 & 1.56 & 1.57 & 1.59 \\
\hline
\end{tabular}

\subsection{Data}

The data collection process was carried out through questionnaire surveys with 12 identified relevant practitioners and industry experts in IBIs in Malaysia from managers' level and above, such as Chief Executive Officer (CEO), Chief Financial Officer (CFO), Chief Operating Officer (COO), Head of Islamic banking department and Head of other relevant departments which has diverse experience and act as the decision-making team in their institutions. Apart from that, 8 other respondents are identified among shariah committees who are appointed as the shariah advisor at individual IBIs in Malaysia. The underlying rationale for the selection of shariah committee as part of the respondents in this study is due to the further expansion on their role and responsibility in the implementation of decisions and opinions relating to shariah matters throughout the IBIs. This has been outlined by the Bank Negara Malaysia in the 'New Shariah Governance Framework' which take effect starting 1st January 2011. Although the sample size looks small but given the nature of the AHP approach, this methodology does not require a large number of experts to take part for generating reliable and useful results. The most important thing, the respondent involved must be the expertise with diversity in terms of their experience related to the subject matter (Saaty, 1994).

Pair-wise comparison is the cornerstone of the AHP principle which allows the respondents to systematically determine the intensities of interrelationships of a great number of decision factors. In this study, almost each respondent was given a detailed explanation of pair-wise comparison given to them preceding the filling of the questionnaire. Basically, respondents are required to indicate their priority choice on the multi-objectives of Islamic banking in the management of assets and liabilities based on their experience and judgment, in which they need to indicate which one of the two objectives are relatively more important than the other and subsequently decides the intensity of that importance. The fundamental 1-9 measurement scale for pair-wise comparison between two elements as proposed by Saaty (1994) was adapted in the questionnaire for the intensity assessment as shown in Table 3. 
Table 3. The fundamental 1- 9 measurement scale for pair-wise comparison between two elements.

\begin{tabular}{|c|l|l|}
\hline $\begin{array}{c}\text { Intensity of } \\
\text { Importance }\end{array}$ & \multicolumn{1}{|c|}{ Definition } & \multicolumn{1}{c|}{ Explanation } \\
\hline $\mathbf{1}$ & Equally importance & When two objectives are equally important \\
\hline $\mathbf{3}$ & $\begin{array}{l}\text { Moderately } \\
\text { importance }\end{array}$ & $\begin{array}{l}\text { Experience and judgment slightly favor one objective over } \\
\text { another }\end{array}$ \\
\hline $\mathbf{5}$ & Strongly importance & $\begin{array}{l}\text { Experience and judgment strongly favor one objective over } \\
\text { another }\end{array}$ \\
\hline $\mathbf{7}$ & $\begin{array}{l}\text { Very strongly } \\
\text { importance }\end{array}$ & $\begin{array}{l}\text { An objective is favored very strongly over another and its } \\
\text { dominance demonstrated in practice }\end{array}$ \\
\hline $\mathbf{9}$ & $\begin{array}{l}\text { Extremely } \\
\text { importance }\end{array}$ & $\begin{array}{l}\text { The evidence favoring one objective over another is of the } \\
\text { highest possible order of affirmation }\end{array}$ \\
\hline $\mathbf{2 , 4 , 6 , 8}$ & $\begin{array}{l}\text { Intermediates } \\
\text { values }\end{array}$ & $\begin{array}{l}\text { Used to represent compromise judgment between the } \\
\text { preferences listed above }\end{array}$ \\
\hline
\end{tabular}

\section{Findings}

After determining the weights of the objectives within each hierarchy, the consistency ratio (CR) is then computed to verify the credibility and reasonability of evaluation and to check whether there is inconsistent or variability of judgment by respondents. Generally, the CR of less than 0.1 indicates that the result is acceptable where the assessment by the respondent is logically sound and not based on a random prioritization (Saaty, 1980). In other words, CR provides a very good estimation on the consistency of the respondents in answering the questions. Out of 20 respondents, there were 17 sets of pair-wise questionnaires shown to have acceptable level of consistency.

All of the questionnaires that had acceptable consistency were than aggregated to obtain the combined judgments on the weight of the objectives at each hierarchy level by using geometric mean aggregation method. As suggested by Saaty (2001), the use of geometric means provides an effective way to aggregate group decision weights. In this study, the CR is assessed according to the two different groups of judgments and opinions from respondents, where one group are more inclined towards the economic objectives while the other group are more concerned with social objectives.

In the first level of hierarchy, the relative importance of the five main objectives is shown in Table 4 . When examining Table 4, it shows that both groups place higher importance on two different objectives, namely profitability and fair $\&$ justice, although the group that inclined to social objectives has a more evenly-distributed spread of relative importance among the five objectives. It is obvious that the group which is more concerned on economic objectives places more weight on the objectives which relates to solvency, liquidity and profitability, while the group which is inclined towards social objectives places their priority more on fair \& justice as well as social welfare.

Table 4. Geometric mean on the main objectives of Islamic banks from two different groups of judgments and opinions 


\begin{tabular}{|l|c|c|}
\hline & $\begin{array}{c}\text { Group that inclined to economic } \\
\text { objectives }\end{array}$ & $\begin{array}{c}\text { Group that inclined to social } \\
\text { objectives }\end{array}$ \\
\hline Profit and growth & 0.4161 & 0.1010 \\
\hline Liquidity & 0.1669 & 0.0878 \\
\hline Solvency & 0.1953 & 0.1776 \\
\hline Fair and Justice & 0.1481 & 0.3700 \\
\hline Social Welfare & 0.0733 & 0.2634 \\
\hline $\begin{array}{l}\text { Consistency } \\
\text { ratios (CR) }\end{array}$ & $\mathbf{0 . 0 4 6 5}$ & $\mathbf{0 . 0 5 1 2}$ \\
\hline
\end{tabular}

When we move down to the sub-objectives of Islamic banks which regards to the management of assets and liabilities, we discover a larger degree of variance in terms of the relative importance of the more specific objectives placed by these two opinion groups. This is shown in Table 5 below. With further subdivided objectives, the result reveals the consistency on the priority choices by the group that inclined to economic objectives and social objectives respectively.

Table 5: Comparison on the sub-objectives of Islamic banks from 2 different groups of judgments and opinions

\begin{tabular}{|c|l|c|l|c|}
\hline Rank & \multicolumn{2}{|c|}{$\begin{array}{c}\text { Group that inclined to } \\
\text { economic objectives }\end{array}$} & \multicolumn{2}{c|}{$\begin{array}{c}\text { Group that inclined to } \\
\text { social objectives }\end{array}$} \\
\hline 1 & Maximizing profitability & 0.2337 & Investment in public interest & 0.3418 \\
\hline 2 & Managing risks & 0.1876 & $\begin{array}{l}\text { Redistribution of income or } \\
\text { wealth }\end{array}$ & 0.2599 \\
\hline 3 & $\begin{array}{l}\text { Providing fair return to } \\
\text { shareholders }\end{array}$ & 0.1846 & $\begin{array}{l}\text { Providing relevant benefits } \\
\text { to employees }\end{array}$ & 0.1033 \\
\hline 4 & $\begin{array}{l}\text { Maintaining sufficient amount } \\
\text { of cash flows }\end{array}$ & 0.1416 & $\begin{array}{l}\text { Providing fair return to } \\
\text { depositors }\end{array}$ & 0.0969 \\
\hline 5 & $\begin{array}{l}\text { Providing fair return to } \\
\text { depositors }\end{array}$ & 0.0972 & $\begin{array}{l}\text { Providing fair return to } \\
\text { shareholders }\end{array}$ & 0.0628 \\
\hline 6 & $\begin{array}{l}\text { Redistribution of income or } \\
\text { wealth }\end{array}$ & 0.0600 & Maximizing profitability & 0.0523 \\
\hline 7 & $\begin{array}{l}\text { Providing relevant benefits to } \\
\text { employees }\end{array}$ & 0.0564 & $\begin{array}{l}\text { Maintaining sufficient } \\
\text { amount of cash flows }\end{array}$ & 0.0434 \\
\hline 8 & Investment in public interest & 0.0389 & Managing risks & 0.0397 \\
\hline
\end{tabular}

As for the former group, emphasizing more on economic objective attributes has been due to several constraining factors that have bearing on some of their decision parameters. Among the important reason shared by one of the respondent lies on the shareholding structure of the Islamic banking entity itself. For instance, IBIs which have no controlling or major shareholder influencing the bank's strategic direction, may have more discretion to balance between economic vis-à-vis social objectives as compared to a fully owned subsidiary of a conventional financial group, which has to demonstrate profitability first in order to garner support for more capital investments to grow the bank.

In comparison to the latter group which their opinions tilting more towards social objectives, they have place higher importance on both the investment in public interest and redistribution of income or wealth under the social-welfare attributes. The importance of the first objective has to do with the channeling of funds to the real economic sectors that the bank invested in which have direct implications to the wider population, especially those in the rural areas. Such sectors might include small and medium enterprise business, agriculture, fisheries, manufacturing and construction. One of the examples for such socially 
responsible investments is through the microfinance or microcredit scheme program. Similarly, the second objective was given a much higher weighting by this group than another group since a major concern to them is the importance of transfer of income and wealth adequately by the IBIs to the poor and the needy, thereby helping to bridge the inequality gap between the rich and the unfortunate.

A further observation is noted from one of the sub-objectives, which is providing fair return to depositors which falls under the main objective of fair and justice. Both two groups weight the objective more or less the same in each group. This implies that both groups are similarly concerned on the accountability of their institutions on the management of financial resources to secure reasonable returns to depositors since low depositor returns will cause the withdrawal of funds and possibly lead to the failure of the bank.

With regards to the degree of importance for providing relevant benefits to employees, group that concerned with social objectives apparently outweighed the other group by approximately $5 \%$. On the other hand, providing fair return to shareholders has been placed higher priority by the group that inclined to economic objectives by more than $12 \%$ differ from the other group of opinion. These results indicate that the group which in favor to social objectives perceived human resource as one of the critical contributing factors for the success of IBIs. Thus, they believe by providing their employees with sufficient exposure through training, seminars and workshops as part of the benefits from the employer, the employees will be well equipped with knowledge to handle their customers and to perform their duties in a proactive way in meeting the objectives of the IBIs. This finding supports the study by Zairani, Rohaya and Hafizi (2008) on the analysis of bankers' perceptions regarding the issue on the training and experience gained in IBIs. Meanwhile, providing fair return to shareholders has been weighted higher in accordance to the profitability attribute by the group which inclined to economic objectives is probably because in achieving high returns to shareholders, it would require more profitability investments (which are long-term investments).

\section{Conclusion}

In conclusion, the significance of this present study is that it proposes the usage of AHP methodology in deriving priority on the multi-objectives model of Islamic banks towards the management of assets and liabilities which take into consideration both economic and social objectives. By trying to investigate the appropriate weight for each of the objectives involved from the experts in IBIs, this study obtained several important findings. First, variance of experts' opinion may influence the result of AHP weight. Thus, two groups of judgments and opinions regarding the subject matter in this study have been aggregated separately to clearly show that there are discrepancies exist among experts' opinion, where one group is more inclined towards the economic objectives while the other group is more concerned with social objectives. Second, the findings of this study have shown that further consideration is needed by the decision makers in IBIs in an effort to reduce the gap between these two objectives in the Islamic banking operations as a whole. Finally, the findings is essential to further explore the possibility of the outcomes in seeking to maximize the objective function which has the elements of social welfare and justice as well as economic objectives for the process of financial resource allocation which is commonly known as asset liability management (ALM) in the banking operation based on the priority weights derived in this study. Since AHP is a flexible decision making tool, the priority weights will be later integrated to other tool such as goal programming to maximize the above multiple objective functions of Islamic banking.

\section{REFERENCES}


Ariff, M. (1988). Islamic banking. Asian-Pasific Economic Literature, 2(2) September, 48-64.

Asyraf Wajdi, D. (2008). Understanding the objectives of Islamic banking: A survey of stakeholders' perspectives. International Journal of Islamic and Middle Eastern Finance and Management, 1(2), 132148.

Bidabad, B. \& Allahyarifard, M. (2008). Assets and liabilities management in Islamic banking. Paper presented at the $3^{\text {rd }}$ International Conference on Islamic banking and Finance, Karachi, Pakistan, 24-25 March.

Chapra, M.U. (1985). Towards a just monetary system. Leicester: The Islamic Foundation.

Chapra, M.U.(2000). Islam and economic challenge. Leicester: The Islamic Foundation.

Griffin, R.W. (2011). Management. South-western, Texas: Cengage Learning.

Haron, S. (1995). The philosophy and objective of Islamic banking: Revisited. New York : New Horizon.

Iqbal, M. and Llewellyn, D.T.L. (2002). Islamic banking and finance: New perspectives on profit-sharing and risk. Edward Elgar Publishing.

Ismail, A.G. (2010). Money, Islamic banking and real economy. Singapore: Cengage Learning Asia Pte. Ltd.

Ismail, A.G. (2011). The theory of Islamic banking: Look back to original idea. Journal of Islamic Economics, banking and Finance, 7(3), 9-22.

ISRA (2011). Islamic financial system principles \& operations. International Shari'ah Research Academy for Islamic Finance, Malaysia.

Khan, M.A. (2003). Islamic Economics \& Finance. New York: Routledge.

Naqvi, S.N.H (2003). Perspective on morality and human well-being: A contribution to Islamic Economics. Leicester: The Islamic Foundation.

Rafiq, I.B. and Jamal, A.B. (2005). Balancing ethical responsibility among multiple organizational stakeholders: The Islamic perspective. Journal of Business Ethics, 60(2), 131-145.

Saaty T. L. (1977). A Scaling Method for Priorities in Hierarchical Structures. Journal of Mathematical Psychology, 5, 234-281.

Saaty, T.L. (1980). The analytical hierarchy process. New York: McGraw-Hill.

Saaty, T.L. (1990). Eigenvector and logarithmic least squares. European Journal of Operational Research 48, 156-160.

Saaty, T.L. (1994). How to make a decision: the analytic hierarchy process. Interfaces, 24(6), 19-43.

Saaty, T.L. (2001). Decision making for leaders: The analytic hierarchy process for decision in a complex world. Pittsburgh: RWS Publications. 
Proceedings of the International Symposium on the Analytic Hierarchy Process 2013

Siddiqi, M. N. (2000). Islamic banks: Concept, Precept and Prospects. Review of Islamic Economics, 9, 21-35.

Zairani, Z., Rohaya, S. \& Hafizi, M.A. (2008). A Comparative Analysis of Bankers Perceptions on Islamic Banking. International Journal of Business and Management, 3(4), 157-168. 